Article

\title{
Development and Validation of Analytical Method for SH-1242 in the Rat and Mouse Plasma by Liquid Chromatography/Tandem Mass Spectrometry
}

\author{
Yoo-Seong Jeong ${ }^{1}{ }^{(\mathbb{D}}$, Minjeong Baek ${ }^{1}$, Seungbeom Lee ${ }^{1,2}{ }^{,}$Min-Soo Kim ${ }^{1}$, Han-Joo Maeng ${ }^{3}$, \\ Jong-Hwa Lee ${ }^{4} \mathbb{D}$, Young-Ger Suh ${ }^{1,2}$ and Suk-Jae Chung ${ }^{1, *}$ \\ 1 College of Pharmacy and Research Institute of Pharmaceutical Sciences, Seoul National University, \\ 1 Gwanak-ro, Gwanak-gu, Seoul 08826, Korea; jus2401@snu.ac.kr (Y.-S.J.); jormungand@snu.ac.kr (M.B.); \\ lastchaos21c@snu.ac.kr (S.L.); misol@snu.ac.kr (M.-S.K.); ygsuh@cha.ac.kr (Y.-G.S.) \\ 2 College of Pharmacy, CHA University, 120 Haeryong-ro, Pocheon-si, Gyeonggi-do 11160, Korea \\ 3 College of Pharmacy, Gachon University, 191 Hambakmoei-ro, Yeonsu-gu, Incheon 21936, Korea; \\ hjmaeng@gachon.ac.kr \\ 4 Korea Institute of Toxicology, 141 Gajeong-ro, Yuseong-gu, Daejeon 34114, Korea; jhl@kitox.re.kr \\ * Correspondence: sukjae@snu.ac.kr; Tel.: +82-2-880-9176
}

Received: 20 December 2019; Accepted: 20 January 2020; Published: 25 January 2020

\begin{abstract}
SH-1242, a novel inhibitor of heat shock protein 90 (HSP90), is a synthetic analog of deguelin: It was previously reported that the treatment of SH-1242 led to a strong suppression of hypoxia-mediated retinal neovascularization and vascular leakage in diabetic retinas by inhibiting the hypoxia-induced upregulation of expression in hypoxia-inducible factor $1 \alpha(\mathrm{HIF}-1 \alpha)$ and vascular endothelial growth factor (VEGF). In this study, an analytical method for the quantification of SH-1242 in biological samples from rats and mice was developed/validated for application in pharmacokinetic studies. SH-1242 and deguelin, an internal standard of the assay, in plasma samples from the rodents were extracted with methanol containing $0.1 \%$ formic acid and analyzed at $\mathrm{m} / \mathrm{z}$ transition values of $368.9 \rightarrow 151.0$ and $395.0 \rightarrow 213.0$, respectively. The method was validated in terms of accuracy, precision, dilution, matrix effects, recovery, and stability and shown to comply with validation guidelines when it was used in the concentration ranges of $1-1000 \mathrm{ng} / \mathrm{mL}$ for rat plasma and of $2-1000 \mathrm{ng} / \mathrm{mL}$ for mouse plasma. SH-1242 levels in plasma samples were readily determined using the developed method for up to $480 \mathrm{~min}$ after the intravenous administration of $0.1 \mathrm{mg} / \mathrm{kg}$ SH-1242 to rats and for up to $120 \mathrm{~min}$ to mice. These findings suggested that the current method was practical and reliable for pharmacokinetic studies on SH-1242 in preclinical animal species.
\end{abstract}

Keywords: SH-1242; 2-(3,4-dimethoxyphenyl)-1-(5-methoxy-2,2-dimethyl-2H-chromen-6-yl)ethanone; pharmacokinetics; HPLC-MS/MS

\section{Introduction}

Heat shock protein 90 (HSP90) is a chaperone protein that plays a vital role in the regulation of its target proteins via stabilizing them under cellular stresses, post-translational folding, and degrading damaged proteins [1]. Hypoxia-inducible factor 1 (HIF-1), one of the client proteins of HSP90, is a transcription factor that is associated with the promotion of angiogenesis in regions of vascular dysfunction, e.g., hypoxic cancer environments. HIF-1 has also been reported to facilitate the expression of vascular endothelial growth factor (VEGF) [2,3] and to be pathologically related to diabetic retinopathy and age-related macular degeneration, as well as cancers $[4,5]$. Deguelin is a naturally occurring rotenoid, a flavonoid, and has been shown to inhibit HSP90's function [6]. Although its underlying mechanism has not been fully delineated, this inhibition appears to be 
related to the attenuation of the binding of clients to ATP-binding pocket of HSP90 by deguelin and to the accelerated decomposition of HIF-1 [6]. Previously, a variety of deguelin analogs were synthesized and screened for HSP90 inhibition [7,8]. In particular, we noted that SH-1242 (2-(3,4-dimethoxyphenyl)-1-(5-methoxy-2,2-dimethyl-2H-chromen-6-yl)ethanone) possessed a potent anti-proliferative activity against human cancer cells [9] and suppressed hypoxia-mediated retinal neovascularization/vascular leakage in diabetic retinas [10]. Furthermore, potent antitumor effects of SH-1242 were also found in various cancer cell lines and in vivo animal models with significantly reduced neurotoxicity [11], suggesting SH-1242 is a reasonable candidate as an experimental inhibitor of HSP90.

Since SH-1242 was found to exhibit a strong antiangiogenic activity in the low nM range (e.g., an effective concentration of approximately down to $10 \mathrm{nM}$ in in vitro model of hypoxia-mediated angiogenesis) [10], a sensitive/robust quantification method for SH-1242, especially in complex biological matrices (e.g., plasma samples), is required for the further development of SH-1242 as a new drug. However, previous attempts to develop methodologies for the analyses of deguelin analogs have primarily focused on the determination of rotenoid levels in natural sources [12-15]. In particular, an analytical method capable of quantifying deguelin analogs in the nano-molar range in biological matrices from animal species used for preclinical study settings was not reported. Therefore, the objective of this study was to develop and validate an analytical method for the determination of SH-1242 in plasma samples of rats and mice in accordance with the U.S. Food and Drug Administration (US FDA) guidance [16]. We were particularly interested in developing the assay capable of measuring the rotenoid analogs at the lower limit of quantification (LLOQ) down to low $\mathrm{ng} / \mathrm{mL}$ range for the application of the devised method to pharmacokinetic studies in the preclinical animal species.

\section{Results and Discussion}

\subsection{Mass Spectrometry and Chromatography}

Based on the chemical structures and product-ion spectra of SH-1242 and internal standard (IS) (Figure 1), $m / z$ transition values were set at $368.9 \rightarrow 151.0$ for SH-1242 and 395.0 $\rightarrow 213.0$ for the IS (deguelin). For the IS, this $\mathrm{m} / \mathrm{z}$ transition value was comparable to the fragmentation pattern found in the literature [12,17]. Isocratic flow with the run time of $3 \mathrm{~min}$ per sample resulted in adequate chromatographic separations for SH-1242 and IS without any apparent interfering peaks (Supplementary Figure S1). SH-1242 and the IS were adequately resolved with the retention times of $1 \mathrm{~min}$ for SH-1242 and $0.96 \mathrm{~min}$ for IS. These observations indicated that the analytical method in this study allowed adequate throughput for the chromatographic separation of SH-1242 with a reasonable resolution. Therefore, the chromatographic conditions were used for subsequent analyses. 
(A)

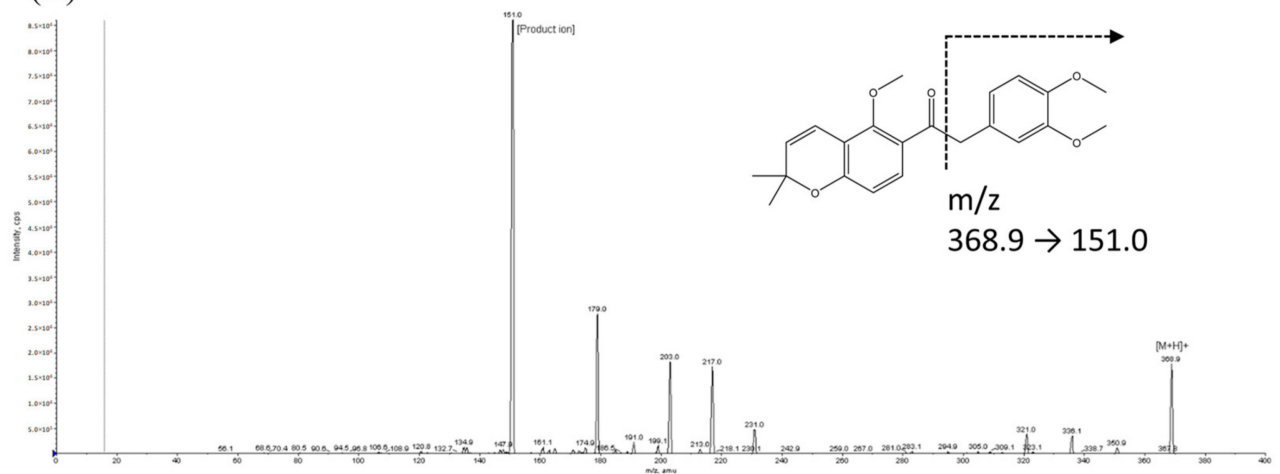

(B)

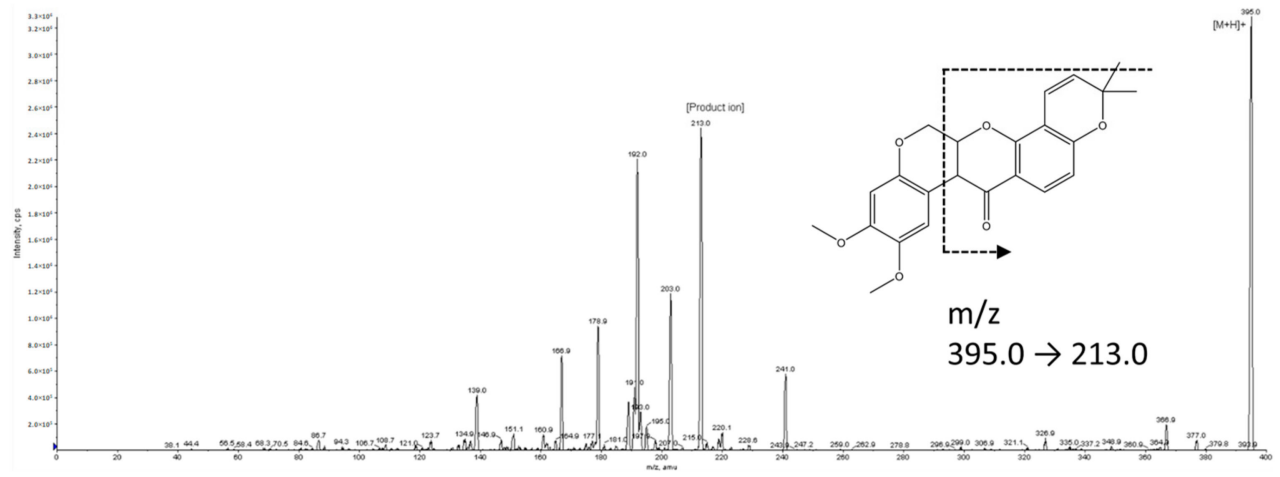

Figure 1. The product-ion scan spectra and proposed multiple reaction monitoring (MRM) transitions of (A) SH-1242 and (B) deguelin, (the internal standard).

\subsection{Selectivity}

Representative ion chromatograms of double blanks, zero blanks, and lower limit of quantification (LLOQ) samples are shown in Supplementary Figure S1. The results obtained from six replicates of double blank, zero blank, and LLOQ samples showed that no appreciable interfering peak was evident in the vicinity of the retention times for the analyte and IS peaks (Table 1). At the LLOQ level $(1 \mathrm{ng} / \mathrm{mL}$ for rat plasma and $2 \mathrm{ng} / \mathrm{mL}$ for mouse plasma), the precision of the peak area was found to be $5.15 \%$ and $10.5 \%$ for rat and mouse plasma, respectively. Taken together, these observations showed that the current HPLC-MS/MS assay provided adequate selectivity for the analysis of SH-1242 in rat and mouse plasma samples.

Table 1. The specificity of SH-1242 in rat and mouse plasma.

\begin{tabular}{|c|c|c|c|c|c|c|c|c|}
\hline \multirow{3}{*}{$\begin{array}{l}\text { MATRIX } \\
\text { LOT }\end{array}$} & \multicolumn{8}{|c|}{ Response (Peak Area) } \\
\hline & \multicolumn{4}{|c|}{ Rat Plasma } & \multicolumn{4}{|c|}{ Mouse Plasma } \\
\hline & $\begin{array}{l}\text { Double } \\
\text { Blank }^{a}\end{array}$ & $\begin{array}{c}\text { Zero } \\
\text { Blank }{ }^{b}\end{array}$ & $\begin{array}{c}\text { LLOQ } \\
(1 \mathrm{ng} / \mathrm{mL})\end{array}$ & $\begin{array}{c}\text { HQC } \\
(800 \mathrm{ng} / \mathrm{mL})\end{array}$ & $\begin{array}{l}\text { Double } \\
\text { Blank }\end{array}$ & $\begin{array}{c}\text { Zero } \\
\text { Blank }\end{array}$ & $\begin{array}{c}\text { LLOQ } \\
(2 \mathrm{ng} / \mathrm{mL})\end{array}$ & $\begin{array}{c}\text { HQC } \\
(800 \mathrm{ng} / \mathrm{mL})\end{array}$ \\
\hline 1 & 0 & 0 & 209 & 71,500 & 0 & 0 & 150 & 23,800 \\
\hline 2 & 0 & 0 & 214 & 80,700 & 0 & 0 & 137 & 24,500 \\
\hline 3 & 0 & 0 & 212 & 77,100 & 0 & 0 & 121 & 22,100 \\
\hline 4 & 0 & 0 & 225 & 78,000 & 0 & 0 & 119 & 22,400 \\
\hline 5 & 0 & 0 & 238 & 77,600 & 0 & 0 & 114 & 23,700 \\
\hline 6 & 0 & 0 & 211 & 77,200 & 0 & 0 & 134 & 24,400 \\
\hline Mean & 0 & 0 & 218 & 77,000 & 0 & 0 & 129 & 23,500 \\
\hline $\mathrm{CV}(\%)^{\mathrm{c}}$ & 0 & 0 & 5.15 & 3.91 & 0 & 0 & 10.5 & 4.30 \\
\hline
\end{tabular}

a Double blank: sample containing no analyte or IS. ${ }^{\mathrm{b}}$ Zero blank: sample containing only IS. ${ }^{\mathrm{c}}$ Coefficient of variation $(\mathrm{CV} \%)=($ standard deviation/mean $) \times 100$. IS: internal standard, LLOQ: lower limit of quantification, HQC: high QC. 


\subsection{LLOQ and Linearity}

The concentration levels of SH-1242 at which the signal-to-noise ratio was consistently 10 or more with acceptable precision (i.e., less than $20 \% \mathrm{CV}$ ) was found to be $1 \mathrm{ng} / \mathrm{mL}$ for rat plasma and $2 \mathrm{ng} / \mathrm{mL}$ for mouse plasma. Calibration curves (Supplementary Figure S2), including the LLOQ, were apparently linear over the specified concentration ranges for rat and mouse plasma (Table 2). Consistent with this statement, the correlation coefficients (i.e., $R$ values with the weighting factor of $1 / \mathrm{x}^{2}$ ) of the calibration curves ranged from 0.995 to 0.999 , with all the calibrators found to be within the acceptance criterion of $15 \%$ (20\% at LLOQ).

Table 2. Calibration curves for SH-1242 in rat and mouse plasma.

\begin{tabular}{ccccccc}
\hline \multirow{2}{*}{ Run } & \multicolumn{3}{c}{ Rat Plasma } & \multicolumn{3}{c}{ Mouse Plasma } \\
\cline { 2 - 7 } & Slope & Intercept & $\mathbf{R}$ & Slope & Intercept & $\mathbf{R}$ \\
\hline 1 & 0.00349 & 0.00340 & 0.999 & 0.00633 & 0.00982 & 0.995 \\
2 & 0.00329 & 0.00281 & 0.999 & 0.00450 & 0.00679 & 0.999 \\
3 & 0.00339 & 0.00227 & 0.998 & 0.00515 & 0.00378 & 0.999 \\
4 & 0.00335 & 0.00402 & 0.999 & 0.00583 & 0.00897 & 0.996 \\
5 & 0.00337 & 0.00417 & 0.999 & 0.00616 & 0.00194 & 0.998 \\
Mean & 0.00338 & 0.00333 & 0.999 & 0.00559 & 0.00626 & 0.997 \\
$\mathrm{CV}(\%)^{\text {a }}$ & 2.16 & - & - & 13.6 & - & - \\
\hline \multicolumn{3}{c}{${ }^{\text {a }}$ Coefficient of variation $(\mathrm{CV} \%)$} & $=$ (standard deviation/mean) $\times 100$. \\
\end{tabular}

\subsection{Accuracy, Precision, and Dilution Integrity}

The accuracies and precisions of QC samples of SH-1242 in rat and mouse plasma are summarized in Table 3. Intra-day (inter-day) precisions of QC samples ranged from 3.85\% to $12.7 \%$ ( $2.84 \%$ to $12.8 \%$ ) and from $2.55 \%$ to $3.09 \%$ (3.57\% to $6.72 \%$ ) for the rat and mouse plasma, respectively; the intra-day (inter-day) accuracies (as a relative error, RE\%) of QC samples ranged from $-5.15 \%$ to $4.83 \%(-2.83 \%$ to $4.63 \%)$ in rat plasma and $-6.02 \%$ to $1.42 \%(-2.53 \%$ to $1.63 \%)$ in mouse plasma. In addition, when SH-1242 samples of concentration of $8000 \mathrm{ng} / \mathrm{mL}$ (i.e., exceeding the ULOQ of $1000 \mathrm{ng} / \mathrm{mL}$ ) were 10 -fold diluted, calculated mean intra-day (inter-day) concentrations were $764 \mathrm{ng} / \mathrm{mL}(743 \mathrm{ng} / \mathrm{mL}$ ) with a CV value of $1.39 \%(2.84 \%)$ for rats and $757 \mathrm{ng} / \mathrm{mL}(782 \mathrm{ng} / \mathrm{mL})$ with a CV value of $4.47 \%(6.72 \%)$ for mice, indicating that plasma samples with SH-1242 concentrations exceeding ULOQ could be diluted for analysis. Taken together, these results indicated that the current assay was accurate and precise for the estimation of SH-1242 concentration in plasma samples obtained from rats or mice.

Table 3. Accuracy and precision of SH-1242 determinations in rat and mouse quality control (QC) samples.

\begin{tabular}{|c|c|c|c|c|c|c|c|c|c|c|}
\hline \multirow{3}{*}{ Batch } & \multicolumn{5}{|c|}{$\begin{array}{l}\text { Rat Plasma } \\
\text { Theoretical Concentration }(\mathrm{ng} / \mathrm{mL})\end{array}$} & \multicolumn{5}{|c|}{$\begin{array}{l}\text { Mouse Plasma } \\
\text { Theoretical Concentration (ng/mL) }\end{array}$} \\
\hline & LLOQ & LQC & MQC & HQC & $\mathrm{HQC}^{\mathrm{a}}$ & LLOQ & LQC & MQC & HQC & $\mathrm{HQC}^{\mathrm{a}}$ \\
\hline & 1 & 2 & 40 & 800 & 800 & 2 & 4 & 40 & 800 & 800 \\
\hline \multicolumn{11}{|c|}{ Intra-day $(n=6)$} \\
\hline Mean & 1 & 1.98 & 41.9 & 759 & 764 & 1.95 & 4.06 & 39.7 & 752 & 757 \\
\hline Precision $(\mathrm{CV} \%)^{\mathrm{b}}$ & 12.7 & 4.64 & 4.41 & 3.85 & 1.39 & 2.56 & 2.55 & 2.96 & 3.09 & 4.47 \\
\hline Accuracy $(\mathrm{RE} \%)^{\mathrm{c}}$ & 0.38 & -0.83 & 4.83 & -5.15 & -4.48 & -2.42 & 1.42 & -0.83 & -6.02 & -5.35 \\
\hline \multicolumn{11}{|c|}{ Inter-day $(n=30)$} \\
\hline Mean & 1.04 & 2.04 & 41.9 & 777 & 743 & 1.99 & 4.04 & 40.7 & 780 & 782 \\
\hline Precision $(\mathrm{CV} \%)^{\mathrm{b}}$ & 12.8 & 5.04 & 5.03 & 4.24 & 2.84 & 5.87 & 4.43 & 3.57 & 5.27 & 6.72 \\
\hline Accuracy $(\mathrm{RE} \%)^{\mathrm{c}}$ & 3.95 & 2.22 & 4.63 & -2.83 & -7.15 & -0.73 & 0.91 & 1.63 & -2.53 & -2.30 \\
\hline
\end{tabular}




\subsection{Matrix Effect, Extraction Efficiency, and Recovery}

Matrix effect, recovery, and extraction efficiency for SH-1242 in rat and mouse plasma samples are summarized (Table 4). The mean extraction efficiencies ranged from $107 \%$ to $119 \%$ for rat plasma and from $91.1 \%$ to $107 \%$ for mouse plasma, indicating that the loss of the analyte through the extraction process was not significant in both matrices. However, the matrix effect of SH-1242 ranged from $82.2 \%$ to $92.8 \%$ for rat plasma and from $44.7 \%$ to $48.0 \%$ for mouse plasma. For rats, the recovery (or IS-normalized recovery) of SH-1242 ranged from 91.3\% to 108\% (103\% to 118\%). In line with this, the recovery of other rotenoids from human serum (e.g., rotenone, rotenolone, and deguelin) was reported to be in a range from $92.3 \%$ to $115 \%$ [17]. In contrast, the recovery of SH-1242 after the extraction from mouse plasma was ranged from $43.7 \%$ to $47.8 \%$ (Table 4 ). Collectively, these observations indicated that there were distinct differences in the matrix effects and IS-normalized recoveries of rotenoid compounds in biological matrices between human/rat and mouse. These discrepancies might be related to the different SH-1242 LLOQ values observed for the two matrices (i.e., $1 \mathrm{ng} / \mathrm{mL}$ for rat plasma vs. $2 \mathrm{ng} / \mathrm{mL}$ for mouse plasma): It is possible that factors influencing the detection process of the rotenoids (e.g., electrospray ionization in HPLC-MS/MS interface) $[18,19]$ are different between the matrices. Nevertheless, variabilities in peak responses used for the calculation of the recovery parameters were consistently less than 15\% (Table 4) for rat and mouse plasma. In addition, no appreciable difference was found on essential assay parameters for the two matrices (e.g., accuracies and precisions). Therefore, despite the differences in the matrix effect/recovery in both biological matrices, we assumed that the devised assay was still applicable for pharmacokinetic studies involving the animal species and the applicability subsequently tested.

Table 4. Matrix effect, extraction efficiency, and recovery of the assay for SH-1242 determination in rat and mouse plasma samples.

\begin{tabular}{|c|c|c|c|c|c|c|c|c|}
\hline \multirow{3}{*}{$\begin{array}{c}\text { Nominal } \\
\text { Concentration }(\mathrm{ng} / \mathrm{mL})\end{array}$} & \multirow{2}{*}{$\begin{array}{c}\text { Matrix Effect } \\
(\%)^{a}\end{array}$} & \multirow{2}{*}{$\begin{array}{c}\text { Extraction } \\
\text { Efficiency }(\%)\end{array}$} & \multirow{2}{*}{$\begin{array}{l}\text { Recovery } \\
\qquad(\%)^{c}\end{array}$} & \multirow{2}{*}{$\begin{array}{l}\text { IS-Normalized } \\
\text { Recovery (\%) }\end{array}$} & \multicolumn{4}{|c|}{ CV $(\%)^{d}$} \\
\hline & & & & & \multicolumn{2}{|c|}{ Analyte } & \multicolumn{2}{|c|}{ IS } \\
\hline & \multicolumn{2}{|c|}{ Rat plasma } & & & Set 1 & Set 2 & Set 1 & Set 2 \\
\hline 2 & 92.8 & 107 & 99 & 110 & 9.08 & 2.92 & 5.95 & 2.13 \\
\hline 40 & 90.4 & 119 & 108 & 118 & 7.11 & 6.05 & 2.96 & 2.01 \\
\hline 800 & 82.2 & 111 & 91.3 & 103 & 2.31 & 6.72 & 3.12 & 1.95 \\
\hline \multicolumn{4}{|c|}{ Mouse plasma } & & Set 1 & Set 2 & Set 1 & Set 2 \\
\hline 2 & 45.9 & 101 & 46.3 & 74.4 & 6.38 & 2.92 & 6.77 & 2.13 \\
\hline 40 & 44.7 & 107 & 47.8 & 74.3 & 7.10 & 6.05 & 2.65 & 2.01 \\
\hline 800 & 48 & 91.1 & 43.7 & 73.4 & 10.5 & 6.72 & 7.52 & 1.95 \\
\hline
\end{tabular}

a Matrix effect was calculated by expressing the ratio of the mean peak area of the analyte added after extraction to the mean peak area of neat standard solution (Set 2) of the analyte multiplied by $100 .{ }^{b}$ Extraction efficiency was calculated by dividing the mean peak area of the analyte added before extraction (Set 1) by the mean peak area of the analyte added after extraction multiplied by 100. ${ }^{c}$ Recovery (IS-normalized recovery) was calculated by the ratio of the mean peak area of the analyte (normalized by IS peak area) added before extraction (Set 1 ) to the mean peak area of a neat standard solution of the analyte (normalized by IS peak area) (Set 2) multiplied by 100 . ${ }^{\mathrm{d}} \mathrm{CV}$ was calculated as a standard deviation of the peak area divided by the mean peak area multiplied by 100 .

\subsection{Stability}

The stability of SH-1242 and IS in stock solutions was studied at concentrations of $1 \mathrm{mg} / \mathrm{mL}$ and $500 \mathrm{ng} / \mathrm{mL}$, respectively, under different storage conditions. As summarized in Table 5, the relative responses of SH-1242 and IS stock solutions compared to those at time zero (i.e., the reference value) were ranged from $85.2 \%$ to $109 \%$ and from $86.2 \%$ to $105 \%$, respectively. In addition, when QC samples, containing SH-1242 at three different concentration levels for rat or mouse plasma, were subjected to various handling and storage conditions (Table 6), we found that benchtop stability at room temperature for $24 \mathrm{~h}$, autosampler stability at $4{ }^{\circ} \mathrm{C}$ for 3 days, stability after three freeze-thaw cycles, and long term stability at $4{ }^{\circ} \mathrm{C}$ for 2 weeks were all acceptable with $\mathrm{CV}$ and $\mathrm{RE}$ values ranging from $0.825 \%$ to $8.54 \%$ and $-8.71 \%$ to $4.92 \%$ for rat plasma, and from $0.699 \%$ to $12 \%$ and $-4.08 \%$ to $12 \%$ for mouse plasma, 
respectively. Collectively, these observations suggested that SH-1242 and deguelin were adequately stable in rat and mouse plasma under various handling and storage conditions.

Table 5. Stability of SH-1242 and IS in stock solutions under typical storage conditions.

\begin{tabular}{|c|c|c|c|c|c|c|}
\hline \multirow[b]{2}{*}{ Batch $(n=3)$} & \multicolumn{6}{|c|}{ Response (Peak Area) } \\
\hline & Initial (0 h) & $\begin{array}{l}\text { Room Temp. } \\
(6 \mathrm{~h})\end{array}$ & $\begin{array}{c}\text { Refrigerated } \\
\left(4^{\circ} \mathrm{C}, 24 \mathrm{~h}\right)\end{array}$ & $\begin{array}{c}\text { Refrigerated } \\
\left(4{ }^{\circ} \mathrm{C}\right. \\
2 \text { Weeks })\end{array}$ & $\begin{array}{c}\text { Refrigerated } \\
\left(-20{ }^{\circ} \mathrm{C}\right. \\
2 \text { Weeks })\end{array}$ & $\begin{array}{c}\text { Refrigerated } \\
\left(-80{ }^{\circ} \mathrm{C},\right. \\
2 \text { Weeks })\end{array}$ \\
\hline \multicolumn{7}{|c|}{ SH-1242 ${ }^{a}$} \\
\hline Mean & 18,000 & 19,700 & 19,000 & 15,400 & 16,100 & 16,400 \\
\hline $\mathrm{CV}(\%)^{\mathrm{b}}$ & 3.93 & 13.5 & 11.1 & 9.14 & 5.44 & 3.01 \\
\hline Relative conc. (\%) ${ }^{\mathrm{c}}$ & 100 & 109 & 105 & 85.2 & 89.1 & 90.8 \\
\hline \multicolumn{7}{|c|}{ IS } \\
\hline Mean & 19,100 & 19,200 & 20,000 & 17,600 & 17,400 & 16,400 \\
\hline $\mathrm{CV}(\%)$ & 4.27 & 6.20 & 0.762 & 4.65 & 8.36 & 1.53 \\
\hline Relative conc. (\%) & 100 & 101 & 105 & 92.3 & 91.4 & 86.2 \\
\hline
\end{tabular}

a Stock solutions of $\mathrm{SH}-1242$ were diluted to $50 \mathrm{ng} / \mathrm{mL}$ prior to analysis. ${ }^{\mathrm{b}} \mathrm{CV}(\%)=($ standard deviation $/ \mathrm{mean}) \times 100$.

${ }^{c}$ Relative concentrations (\%) were obtained by dividing measured values by initial values. IS: internal standard

Table 6. Stability of SH-1242 QC samples under typical storage conditions.

\begin{tabular}{|c|c|c|c|c|c|c|}
\hline \multirow{3}{*}{ Batch } & \multicolumn{3}{|c|}{$\begin{array}{l}\text { Rat Plasma } \\
\text { Theoretical Concentration (ng/mL) }\end{array}$} & \multicolumn{3}{|c|}{$\begin{array}{l}\text { Mouse Plasma } \\
\text { Theoretical Concentration }(\mathrm{ng} / \mathrm{mL})\end{array}$} \\
\hline & LQC & MQC & HQC & LQC & MQC & HQC \\
\hline & 2 & $\widehat{40}$ & 800 & $\widetilde{4}$ & $\widehat{40}$ & 800 \\
\hline \multicolumn{7}{|c|}{ Benchtop stability at room temperature $\left(25^{\circ} \mathrm{C}\right)$ for $24 \mathrm{~h}(n=3)$} \\
\hline Mean & 1.87 & 37.3 & 737 & 4.21 & 41.7 & 810 \\
\hline Precision $(\mathrm{CV} \%)^{\mathrm{a}}$ & 6.95 & 4.35 & 2.62 & 9.47 & 4.38 & 5.57 \\
\hline Accuracy $(\mathrm{RE} \%)^{b}$ & -6.33 & -6.83 & -7.88 & 5.25 & 4.25 & 1.25 \\
\hline \multicolumn{7}{|c|}{ Autosampler stability at $4{ }^{\circ} \mathrm{C}$ for 3 days $(n=3)$} \\
\hline Mean & 2.00 & 38.9 & 773 & 4.19 & 42.6 & 863 \\
\hline Precision $(\mathrm{CV} \%)$ & 8.27 & 6.05 & 3.16 & 4.90 & 5.15 & 0.699 \\
\hline Accuracy (RE\%) & -0.167 & -2.75 & -3.33 & 4.67 & 6.50 & 7.83 \\
\hline \multicolumn{7}{|c|}{ Freeze-thaw stability ( 3 cycles, $n=3$ ) } \\
\hline Mean & 1.84 & 41.97 & 780 & 4.45 & 42.4 & 840 \\
\hline Precision $(\mathrm{CV} \%)$ & 3.85 & 4.20 & 3.57 & 2.00 & 4.32 & 1.33 \\
\hline Accuracy (RE\%) & -7.83 & 4.92 & -2.50 & 11.3 & 6.00 & 5.00 \\
\hline \multicolumn{7}{|c|}{ Long term stability at $4{ }^{\circ} \mathrm{C}$ for 2 weeks $(n=3)$} \\
\hline Mean & 2.02 & 37.3 & 730 & 3.84 & 44.8 & 865 \\
\hline Precision $(\mathrm{CV} \%)$ & 8.54 & 2.56 & 0.825 & 12.0 & 1.77 & 4.37 \\
\hline Accuracy (RE\%) & 0.833 & -6.75 & -8.71 & -4.08 & 12.0 & 8.08 \\
\hline
\end{tabular}

\subsection{Applicability of the Assay to Pharmacokinetic Studies}

To determine whether the current assay could be applied to pharmacokinetic studies on SH-1242 in preclinical animal species, $\mathrm{SH}-1242$ was intravenously administered to rats or mice at a dose of $0.1 \mathrm{mg} / \mathrm{kg}$. Concentration-time profiles of SH-1242 in rats and mice are shown in Figure 2, and calculated pharmacokinetic parameters, including $\mathrm{T}_{1 / 2}, \mathrm{CL}$, area under the curve from time zero to infinity $\left(A U C_{\text {inf }}\right)$, mean residence time $(\mathrm{MRT})$, and $\mathrm{V}_{\mathrm{ss}}$, are listed in Table 7 . For rats, $A U C_{\text {inf }}, C L$, $\mathrm{V}_{\mathrm{ss}}$, and $\mathrm{T}_{1 / 2}$ values of SH-1242 were $3350 \pm 573 \mathrm{ng} \cdot \mathrm{min} / \mathrm{mL}, 30.5 \pm 4.49 \mathrm{~mL} / \mathrm{min} / \mathrm{kg}, 4380 \pm 716 \mathrm{~mL} / \mathrm{kg}$, and $146 \pm 59 \mathrm{~min}$, respectively. Interestingly, SH-1242 appeared to have lower systemic clearance and relatively limited distribution space, compared to those of deguelin, a model rotenoid, in rats (e.g., $\mathrm{CL}$ value of $72.7 \mathrm{~mL} / \mathrm{min} / \mathrm{kg}$, and $\mathrm{V}_{\mathrm{ss}}$ value of $30.5 \mathrm{~L} / \mathrm{kg}$ ) [20]. In mice, $\mathrm{AUC}_{\mathrm{inf}}, \mathrm{CL}, \mathrm{V}_{\mathrm{ss}}$, and $\mathrm{T}_{1 / 2}$ values 
of SH-1242 were $1440 \mathrm{ng} \cdot \mathrm{min} / \mathrm{mL}, 69.4 \mathrm{~mL} / \mathrm{min} / \mathrm{kg}, 2060 \mathrm{~mL} / \mathrm{kg}$, and $26.3 \mathrm{~min}$, respectively. In general, SH-1242 concentrations were readily measurable in all plasma samples in both animals at up to $8 \mathrm{~h}$ after the intravenous administration, indicating that the developed method could be readily applicable for the characterization of the pharmacokinetics of SH-1242 in preclinical study settings.
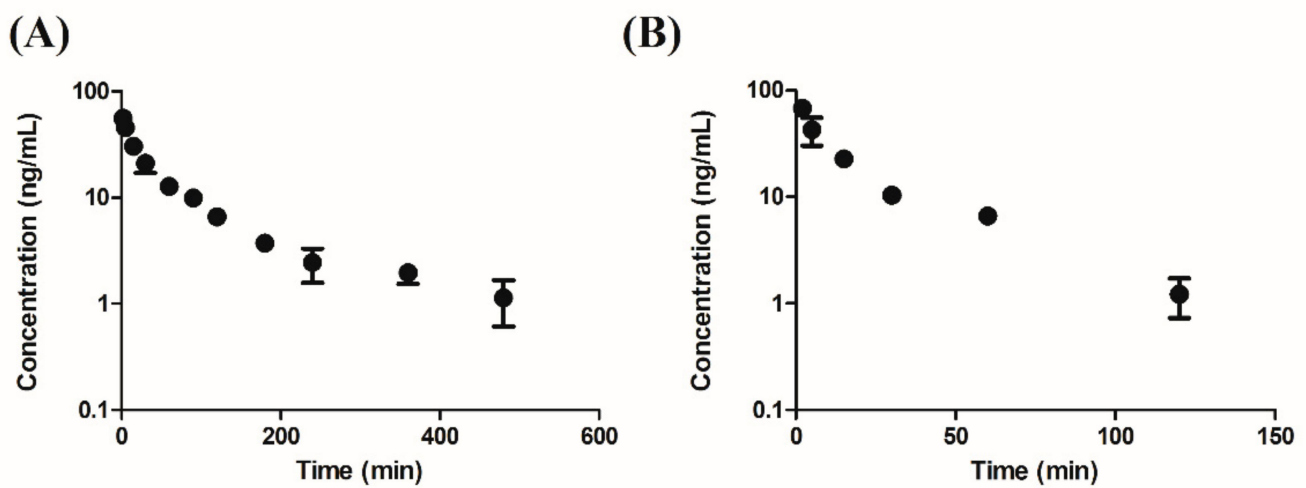

Figure 2. Mean concentration-time profiles of SH-1242 after (A) an intravenous injection of $0.1 \mathrm{mg} / \mathrm{kg}$ SH-1242 $(n=4)$ to rats and (B) an intravenous injection of $0.1 \mathrm{mg} / \mathrm{kg} \mathrm{SH}-1242$ ( $n=3$ for each time point) to mice. Results are presented as means \pm standard deviations.

Table 7. Pharmacokinetic parameters of SH-1242 after a single intravenous administration at a dose of $0.1 \mathrm{mg} / \mathrm{kg}$ to rats and mice.

\begin{tabular}{ccc}
\hline \multirow{2}{*}{ Pharmacokinetic Parameters (Units) } & Rats & Mice \\
\cline { 2 - 3 } & Mean \pm S.D. & Representative $^{\text {a }}$ \\
\hline $\mathrm{T}_{1 / 2}(\mathrm{~min})$ & $146 \pm 59$ & 26.3 \\
$\mathrm{CL}(\mathrm{mL} / \mathrm{min} / \mathrm{kg})$ & $30.5 \pm 4.49$ & 69.4 \\
$\mathrm{AUC}_{\mathrm{inf}}(\mathrm{ng} \cdot \mathrm{min} / \mathrm{mL})$ & $3350 \pm 573$ & 1440 \\
$\mathrm{MRT}(\mathrm{min})$ & $149 \pm 46.9$ & 29.6 \\
$\mathrm{~V}_{\text {ss }}(\mathrm{mL} / \mathrm{kg})$ & $4380 \pm 716$ & 2060 \\
\hline
\end{tabular}

a Because of the study design (i.e., one-time point sample per mouse), the calculation of the standard deviation was not possible for pharmacokinetic parameters in mice.

\section{Materials and Methods}

\subsection{Chemicals, Reagents, and Experimental Animals}

SH-1242 (purity of $>99 \%$ ) and deguelin (purity of $>99 \%$, IS of this study) were synthesized, as previously described [9]. Methanol and acetonitrile (high-performance liquid chromatography (HPLC) grade) were purchased from Fisher Scientific (Pittsburgh, PA, USA). Double-distilled water (DDW) was prepared in-house using a Millipore Simplicity water purification system (Millipore, Bedford, MA, USA). Formic acid (FA) was purchased from Sigma-Aldrich (St. Louis, MO, USA). Blank rat and mouse plasma samples were collected from animals provided by Orient Bio Inc. (Gyeonggi-do, Korea). Experimental protocols involving animals used in this study were carefully reviewed by the Seoul National University Institutional Animal Care and Use Committee (IACUC), in accordance with the 'Principles of Laboratory Animal Care' guideline, published by the National Institutes of Health publication number 85-23, revised 1985 (SNU-170303-1 and SNU-170120-4-4).

\subsection{HPLC Conditions}

A Waters e2695 HPLC system (Milford, MA, USA) consisting of a binary pump, an online degasser, an autosampler, a column heater, and a reversed-phase HPLC column (Poroshell 120 EC-C18 $2.7 \mu \mathrm{m}(4.6 \mathrm{~mm} \times 50 \mathrm{~mm}$, Agilent, Santa Clara, CA, USA)) was used for chromatographic separations. The mobile phase was composed of $0.1 \%$ FA in acetonitrile and 0.1\% FA in DDW in a ratio of 80:20 
and was isocratically delivered at a flow rate of $1 \mathrm{~mL} / \mathrm{min}$. Throughout the assay, the temperatures of analytical samples and the column were maintained at $4{ }^{\circ} \mathrm{C}$ and $25^{\circ} \mathrm{C}$, respectively, and the run time was 3 min for each sample.

\subsection{Mass Spectrometer Conditions}

In this study, mass spectrometric detection was conducted using API 3200 Qtrap ${ }^{\circledR}$ (Applied Biosystems, Foster City, CA, USA), equipped with an electrospray ionization (ESI) source in the positive ion mode. Multiple reaction monitoring (MRM) method was used to quantify the analytes: $\mathrm{m} / \mathrm{z}$ transitions were monitored at $368.9 \rightarrow 151.0$ for SH-1242 and 395.0 $\rightarrow 213.0$ for IS. After a series of optimization studies to secure a sensitive and robust response of the signal, conditions, such as ion spray voltage, source temperature, and the three source gas pressure values (i.e., curtain gas pressure, ion source gas 1 and 2), were determined to be $5000 \mathrm{~V}, 200{ }^{\circ} \mathrm{C}$, and 50 psi, respectively (Supplementary Figure S3). In addition, using the quantitative optimization mode built-in Analyst ${ }^{\mathrm{TM}}$ software (version 1.4.2, Applied Biosystems, Waltham, MA, USA), the following factors were obtained: Declustering potentials for SH-1242 and IS were $41 \mathrm{~V}$ and $61 \mathrm{~V}$, respectively, and entrance potentials were $4.5 \mathrm{~V}$ and $7 \mathrm{~V}$, collision energies were $27 \mathrm{~V}$ and $29 \mathrm{~V}$, and the collision cell exit potential was $4 \mathrm{~V}$ for both analytes. In this study, the Analyst ${ }^{\mathrm{TM}}$ software was used for data acquisition and quantification.

\subsection{Standards and Quality Control (QC) Samples}

Stock solutions of SH-1242 and IS were prepared at the concentrations of $1 \mathrm{mg} / \mathrm{mL}$ and $500 \mathrm{ng} / \mathrm{mL}$ in methanol, respectively. A serial dilution of the SH-1242 stock solution with methanol was carried out to obtain a set of SH-1242 standard solutions, and $5 \mu \mathrm{L}$ aliquots of these standard solutions were added to $45 \mu \mathrm{L}$ of blank plasma to prepare SH-1242 calibration standards at concentrations of $1,2,5,10$, $20,50,100,200,500$, and $1000 \mathrm{ng} / \mathrm{mL}$ for rat plasma and 2, 5, 10, 20, 50, 100, 200, 500, and $1000 \mathrm{ng} / \mathrm{mL}$ for mouse plasma. Using similar dilution protocol, a batch of QC samples for $\mathrm{SH}-1242$ was prepared at concentrations of 1 (LLOQ), 2 (low QC), 40 (mid QC), and $800 \mathrm{ng} / \mathrm{mL}$ (high QC) for rat plasma and 2 (LLOQ), 4 (low QC), 40 (mid QC), and $800 \mathrm{ng} / \mathrm{mL}$ (high QC) for mouse plasma. Samples were then processed according to the procedure described in Section 3.5.

\subsection{Sample Preparation}

A total of $50 \mu \mathrm{L}$ aliquots of plasma samples, calibration standards, or QC samples were transferred to Safeseal Microcentrifuge Tubes (Sorenson BioScience, Murray, UT, USA), followed by the addition of $200 \mu \mathrm{L}$ of IS stock solution. Mixtures were vortex-mixed for $5 \mathrm{~min}$ and centrifuged at 16,100 $\mathrm{g}$ for $5 \mathrm{~min}$ at $4{ }^{\circ} \mathrm{C}$. Supernatants were subsequently transferred to fresh analysis vials (MicroSolv Technology Corporation, Leland, NC, USA), and $50 \mu \mathrm{L}$ aliquots were injected onto the HPLC-MS/MS system. In this study, the injection volume (i.e., $50 \mu \mathrm{L}$ ) was less than $10 \%$ of the void volume of the column of $830 \mu \mathrm{L}$ (i.e., $4.6 \mathrm{~mm}$ of inner diameter and $50 \mathrm{~mm}$ of length) and did not appear to have any appreciable impact on the performance of the instrument (e.g., analyte peak width, retention time, and carryover) [21].

\subsection{Method Validation}

\subsubsection{Selectivity}

Six lots of pooled rat and mouse plasma samples were used to evaluate assay selectivity. The presence of any interfering peak in double blank samples (i.e., blank plasma without SH-1242 or IS), zero blank samples (i.e., blank plasma with IS only), and LLOQ samples was carefully monitored. In this study, assay selectivity was assumed adequate when no apparent interfering peaks were observed in the vicinities of the analyte peaks. 


\subsubsection{LLOQ and Linearity}

The LLOQ of SH-1242 was determined to be the minimum concentration, with a signal-to-noise ratio being consistently greater than 10 . Throughout our preliminary studies, LLOQ values of SH-1242 in the rat and mouse plasma were determined to be $1 \mathrm{ng} / \mathrm{mL}$ and $2 \mathrm{ng} / \mathrm{mL}$, respectively, and these concentrations were subsequently used in the development of the assay. Various concentrations of $\mathrm{SH}-1242$, ranging from $1 \mathrm{ng} / \mathrm{mL}$ to $1000 \mathrm{ng} / \mathrm{mL}$ for rat plasma (ten concentration levels) and $2 \mathrm{ng} / \mathrm{mL}$ to $1000 \mathrm{ng} / \mathrm{mL}$ for mouse plasma (nine concentration levels), were used to determine the linearity of the assay. A calibration curve was constructed by plotting SH-1242-to-IS peak area ratios against nominal $\mathrm{SH}-1242$ concentrations. The linear least-square regression method with a weighting factor of $1 / \mathrm{x}^{2}$ was used to determine the slope and y-intercept.

\subsubsection{Precision, Accuracy, and Dilution Integrity}

Accuracy and precision within and between runs were assessed using five separate batches of QC samples. Each batch consisted of six replicates of QC samples at four concentration levels (LLOQ, 2 or $4 \mathrm{ng} / \mathrm{mL}, 40 \mathrm{ng} / \mathrm{mL}$, and $800 \mathrm{ng} / \mathrm{mL}$, in rat or mouse plasma, respectively). The accuracy of the assay was determined by calculating the percent differences between the calculated and theoretical concentrations, and the precision of the method was defined as the coefficient of variation $(\mathrm{CV})$ percentage at each concentration. The method was considered accurate when the calculated concentrations of QC samples were within $15 \%$ of nominal concentrations. In addition, the assay was considered precise when the CV of calculated concentrations of QC samples was $15 \%$ or less (viz, $20 \%$ CV for LLOQ samples).

When it was necessary to study dilution integrity of the assay, a fresh batch of six-replicate samples $(50 \mu \mathrm{L})$ was first prepared in rat or mouse plasma at an SH-1242 concentration of $8000 \mathrm{ng} / \mathrm{mL}$ (i.e., at a concentration exceeding the upper limit of quantification (ULOQ)). Samples were then diluted 10-fold with blank plasma (with $450 \mu \mathrm{L}$ ) to have the expected plasma concentration of $800 \mathrm{ng} / \mathrm{mL}$ and to bring the final concentration within the calibration range. Diluted samples were then processed and analyzed, as described in Section 3.5.

\subsubsection{Matrix Effect, Extraction Efficiency, and Recovery}

The extent of matrix effect, extraction efficiency, and recovery of SH-1242 in the rat and mouse plasma was evaluated by analyzing three sets of plasma standards at three different concentration levels (2 ng/mL, $40 \mathrm{ng} / \mathrm{mL}$, and $800 \mathrm{ng} / \mathrm{mL}$ ) [22,23]. Pre-spiked extracted samples (Set 1; extracted after the addition of analyte to blank plasma) were prepared according to the procedure described in Section 3.5. Similarly, post-spiked extracted samples were prepared by processing blank plasma and then adding SH-1242 to have the prescribed concentrations. Extraction efficiency was determined by dividing the mean peak areas of pre-spiked extracted samples (Set 1) by those of post-spiked extracted samples. Mean peak areas of the pre- and post-spiked extraction samples were divided by the mean peak areas of neat standard solutions of the analyte in methanol containing $0.1 \%$ FA (Set 2) to determine the recovery and matrix effect, respectively.

\subsubsection{Stability}

The stability of SH-1242 and IS was evaluated under various storage and handling conditions. Stock solutions of SH-1242 and IS at concentrations of $1 \mathrm{mg} / \mathrm{mL}$ and $500 \mathrm{ng} / \mathrm{mL}$, respectively, were stored at room temperature $\left(25^{\circ} \mathrm{C}\right)$ for $6 \mathrm{~h}$, under refrigerated conditions $\left(4^{\circ} \mathrm{C}\right)$ for $24 \mathrm{~h}$ or 2 weeks, or under two different frozen conditions $\left(-20^{\circ} \mathrm{C}\right.$ and $\left.-80^{\circ} \mathrm{C}\right)$ for 2 weeks. Solutions of SH-1242 were diluted to $50 \mathrm{ng} / \mathrm{mL}$ prior to analysis. In addition, QC samples at three different concentrations ( 2 or $4 \mathrm{ng} / \mathrm{mL}, 40 \mathrm{ng} / \mathrm{mL}$, and $800 \mathrm{ng} / \mathrm{mL}$ ) were prepared and processed. The samples were then placed in various handling conditions (i.e., standing in an autosampler $\left(4^{\circ} \mathrm{C}\right.$ for 3 days) or under bench-top condition $\left(25^{\circ} \mathrm{C}\right.$ for $\left.24 \mathrm{~h}\right)$, or subjected to three freeze-thaw cycles, or long-term refrigeration $\left(4{ }^{\circ} \mathrm{C}\right.$ for 2 weeks)). Mean peak areas of stock solutions were compared with those of fresh stock solutions. 
For QC samples, the results were compared with nominal concentrations. In this study, analytes were considered stable under test conditions when accuracies at each concentration were within $15 \%$ of nominal concentration.

\subsection{Application of the Assay to Pharmacokinetic Studies of SH-1242}

To test the applicability of the current assay to pharmacokinetic studies, in preclinical animal species, male Sprague-Dawley rats (weighing 250-270 g) or ICR mice (weighing 18-20 g) were used. Prior to the experiment, animals fasted for $12 \mathrm{~h}$ with free access to water. SH-1242 was dissolved in a dosing vehicle consisting of dimethyl sulfoxide, PEG400 (Sigma-Aldrich, St. Louis, MO, USA), and normal saline in a ratio of 1:6:3 $(v / v / v \%)$, and intravenously bolus-injected to the right femoral vein at $2 \mathrm{~mL} / \mathrm{kg}$ for rats or to the tail vein at $5 \mathrm{~mL} / \mathrm{kg}$ for mice. In this study, the intravenous dose of SH-1242 was set at $0.1 \mathrm{mg} / \mathrm{kg}$ for both species. Blood samples (approximately $150 \mu \mathrm{L}$ each) were collected in heparinized tubes via the right femoral artery at 2, 5, 15, 30, 60, 90, 120, 180, 240, 360, and $480 \mathrm{~min}$ after the administration to rats $(n=4)$ and via the retro-orbital plexus at 2, 5, 15, 30, 60, or 120 min after the administration to mice ( $n=3$ for each time point). For the mouse study, a blood sample was obtained once from each animal, and the animal was sacrificed after collection. Plasma was obtained by centrifuging blood samples at $16,100 \mathrm{~g}$ for $5 \mathrm{~min}$ at $4{ }^{\circ} \mathrm{C}$ and then processed, as described in Section 3.5. The plasma concentration versus time data was analyzed using the non-compartmental method in the WinNonlin software (WinNonlin Professional 5.0.1.; Pharsight, Mountain View, CA, USA) to calculate essential kinetic parameters, such as terminal phase half-life $\left(\mathrm{T}_{1 / 2}\right)$, systemic clearance (CL), and steady-state volume of distribution $\left(\mathrm{V}_{\mathrm{ss}}\right)$.

\section{Conclusions}

A straightforward and rapid HPLC-MS/MS assay was developed and validated for the quantification of SH-1242 in rat and mouse plasma. The method was validated in terms of its selectivity, linearity, accuracy, precision, dilution, matrix effects, recovery, and stability. Assay parameters were found to comply with the acceptance criteria described in U.S. FDA guidelines. The developed assay was found to be suitable for pharmacokinetic studies on SH-1242, involving rats and mice.

Supplementary Materials: The following are available online. Figure S1: Multiple reaction monitoring (MRM) chromatograms of (A) double blank rat plasma, (B) zero blank rat plasma containing $500 \mathrm{ng} / \mathrm{mL}$ IS, (C) rat plasma containing SH-1242 at LLOQ (1 ng/mL) and IS, (D) double blank mouse plasma, (E) zero blank mouse plasma containing $500 \mathrm{ng} / \mathrm{mL}$ IS, and (F) mouse plasma containing SH-1242 at LLOQ (2 ng/mL) and IS. Figure S2: Calibration curves for the LC-MS/MS analysis of SH-1242 in (A) the rat and (B) mouse plasma (i.e., 5 separate runs). Data are presented as means \pm standard deviations. Slopes and intercepts of linear regression lines are showed in Table 2. Figure S3: Dependency of variables related to source/gas on the signal intensity in turbo VTM ion spray ionization mode. Closed circles and error bars represent the mean and upper/lower response of the signal during $1 \mathrm{~min}$ infusion of $\mathrm{SH}-1242$ solution at $1 \mu \mathrm{g} / \mathrm{mL}$ (in 50\% methanolic solution containing $0.1 \%$ FA).

Author Contributions: Conceptualization, Y.-S.J and S.-J.C.; data curation, Y.-S.J., M.B., and M.-S.K.; funding acquisition, H.-J.M. and S.-J.C.; methodology and validation, Y.-S.J., M.B., M.-S.K., H.-J.M., J.-H.L., and S.-J.C.; resources, S.L. and Y.-G.S.; writing-original draft, Y.-S.J., M.B., and S.-J.C.; investigation and writing-review and editing, Y.-S.J., M.B., S.L., M.-S.K., H.-J.M., J.-H.L., Y.-G.S., and S.-J.C.; supervision, S.-J.C. All authors have read and agreed to the published version of the manuscript.

Funding: This research was supported by a grant of the National Research Foundation of Korea (NRF) funded by the Korean government (MSIP) (No. 2009-0083533). In addition, this research was supported by the Basic Science Research Program through the National Research Foundation of Korea (NRF) grant funded by the Korea government (MSIT) (NRF-2019R1F1A1058103).

Conflicts of Interest: The authors declare no conflict of interest.

\section{References}

1. Pearl, L.H.; Prodromou, C.; Workman, P. The Hsp90 molecular chaperone: An open and shut case for treatment. Biochem. J. 2008, 410, 439-453. [CrossRef] 
2. Ke, Q.; Costa, M. Hypoxia-inducible factor-1 (HIF-1). Mol. Pharmacol. 2006, 70, 1469-1480. [CrossRef] [PubMed]

3. Volm, M.; Koomägi, R. Hypoxia-inducible factor (HIF-1) and its relationship to apoptosis and proliferation in lung cancer. Anticancer Res. 2000, 20, 1527-1533.

4. $\quad$ Lin, M.; Chen, Y.; Jin, J.; Hu, Y.; Zhou, K.; Zhu, M.; Le, Y.-Z.; Ge, J.; Johnson, R.; Ma, J.-X. Ischaemia-induced retinal neovascularisation and diabetic retinopathy in mice with conditional knockout of hypoxia-inducible factor-1 in retinal Müller cells. Diabetologia 2011, 54, 1554-1566. [CrossRef]

5. Krishna Vadlapatla, R.; Dutt Vadlapudi, A.; Mitra, A.K. Hypoxia-inducible factor-1 (HIF-1): A potential target for intervention in ocular neovascular diseases. Curr. Drug Targets 2013, 14, 919-935. [CrossRef]

6. Oh, S.H.; Woo, J.K.; Yazici, Y.D.; Myers, J.N.; Kim, W.-Y.; Jin, Q.; Hong, S.S.; Park, H.-J.; Suh, Y.-G.; Kim, K.-W. Structural basis for depletion of heat shock protein 90 client proteins by deguelin. J. Natl. Cancer Inst. 2007, 99, 949-961. [CrossRef]

7. Kim, H.S.; Hong, M.; Ann, J.; Yoon, S.; Nguyen, C.-T.; Lee, S.-C.; Lee, H.-Y.; Suh, Y.-G.; Seo, J.H.; Choi, H. Synthesis and biological evaluation of C-ring truncated deguelin derivatives as heat shock protein 90 (HSP90) inhibitors. Bioorg. Med. Chem. 2016, 24, 6082-6093. [CrossRef]

8. Kim, H.S.; Hong, M.; Lee, S.-C.; Lee, H.-Y.; Suh, Y.-G.; Oh, D.-C.; Seo, J.H.; Choi, H.; Kim, J.Y.; Kim, K.-W. Ring-truncated deguelin derivatives as potent Hypoxia Inducible Factor- $1 \alpha$ (HIF-1 $\alpha$ ) inhibitors. Eur. J. Med. Chem. 2015, 104, 157-164. [CrossRef]

9. Chang, D.-J.; An, H.; Kim, K.-s.; Kim, H.H.; Jung, J.; Lee, J.M.; Kim, N.-J.; Han, Y.T.; Yun, H.; Lee, S. Design, synthesis, and biological evaluation of novel deguelin-based heat shock protein 90 (HSP90) inhibitors targeting proliferation and angiogenesis. J. Med. Chem. 2012, 55, 10863-10884. [CrossRef] [PubMed]

10. Jo, D.H.; An, H.; Chang, D.-J.; Baek, Y.-Y.; Cho, C.S.; Jun, H.O.; Park, S.-J.; Kim, J.H.; Lee, H.-Y.; Kim, K.-W. Hypoxia-mediated retinal neovascularization and vascular leakage in diabetic retina is suppressed by HIF- $1 \alpha$ destabilization by SH-1242 and SH-1280, novel hsp90 inhibitors. J. Mol. Med. (Heidelberg, Ger.) 2014, 92, 1083-1092. [CrossRef] [PubMed]

11. Lee, S.-C.; Min, H.-Y.; Choi, H.; Bae, S.Y.; Park, K.H.; Hyun, S.Y.; Lee, H.J.; Moon, J.; Park, S.-H.; Kim, J.Y. Deguelin analogue SH-1242 inhibits Hsp90 activity and exerts potent anticancer efficacy with limited neurotoxicity. Cancer Res. 2016, 76, 686-699. [CrossRef] [PubMed]

12. Prestes, O.D.; Padilla-Sánchez, J.A.; Romero-González, R.; Grio, S.L.; Frenich, A.G.; Martínez-Vidal, J.L. Comparison of several extraction procedures for the determination of biopesticides in soil samples by ultrahigh pressure LC-MS/MS. J. Sep. Sci. 2012, 35, 861-868. [CrossRef] [PubMed]

13. Caboni, P.; Sarais, G.; Angioni, A.; Garau, V.L.; Cabras, P. Fast and versatile multiresidue method for the analysis of botanical insecticides on fruits and vegetables by HPLC/DAD/MS. J. Agric. Food Chem. 2005, 53, 8644-8649. [CrossRef] [PubMed]

14. Dos Santos Pereira, A.; Serrano, M.A.A.; De Aquino Neto, F.R.; Da Cunha Pinto, A.; Texeira, D.F.; Gilbert, B. Analysis and quantitation of rotenoids and flavonoids in Derris (Lonchocarpus urucu) by high-temperature high-resolution gas chromatography. J. Chromatogr. Sci. 2000, 38, 174-180. [CrossRef]

15. Ye, H.; Chen, L.; Li, Y.; Peng, A.; Fu, A.; Song, H.; Tang, M.; Luo, H.; Luo, Y.; Xu, Y. Preparative isolation and purification of three rotenoids and one isoflavone from the seeds of Millettia pachycarpa Benth by high-speed counter-current chromatography. J. Chromatogr. A 2008, 1178, 101-107. [CrossRef]

16. FDA. Guidance for Industry: Bioanalytical Method Validation; US Department of Heath and Human Services Food and Drug Administration: Rockville, MD, USA, 2018.

17. Caboni, P.; Sarais, G.; Vargiu, S.; De Luca, M.A.; Garau, V.L.; Ibba, A.; Cabras, P. LC-MS-MS determination of rotenone, deguelin, and rotenolone in human serum. Chromatographia 2008, 68, 739-745. [CrossRef]

18. Jacobson, B.-M.; Olsson, A.; Fakt, C.; Öhman, D. The use of human plasma as matrix for calibration standards in pre-clinical LC-MS/MS methods-A way to reduce animal use. J. Pharm. Biomed. Anal. 2011, 54, 826-829. [CrossRef]

19. Matuszewski, B.; Constanzer, M.; Chavez-Eng, C. Strategies for the assessment of matrix effect in quantitative bioanalytical methods based on HPLC- MS/MS. Anal. Chem. 2003, 75, 3019-3030. [CrossRef]

20. Udeani, G.O.; Zhao, G.-M.; Shin, Y.G.; Kosmeder Ii, J.W.; Beecher, C.W.; Kinghorn, A.D.; Moriarty, R.M.; Moon, R.C.; Pezzuto, J.M. Pharmacokinetics of deguelin, a cancer chemopreventive agent in rats. Cancer Chemother. Pharmacol. 2001, 47, 263-268. [CrossRef]

21. Kromidas, S. More practical problem solving in HPLC; John Wiley \& Sons: Weinheim, Germany, 2008. 
22. Lee, J.H.; Woo, Y.A.; Hwang, I.C.; Kim, C.Y.; Kim, D.D.; Shim, C.K.; Chung, S.J. Quantification of CKD-501, lobeglitazone, in rat plasma using a liquid-chromatography/tandem mass spectrometry method and its applications to pharmacokinetic studies. J. Pharm. Biomed. Anal. 2009, 50, 872-877. [CrossRef]

23. Lee, M.; Kim, D.; Shin, J.; Lee, H.-Y.; Park, S.; Lee, H.-S.; Kang, J.-H.; Chung, S.-J. Quantification of IDP-73152, a novel antibiotic, in plasma from mice, rats and humans using an ultra-high performance liquid chromatography/tandem mass spectrometry method for use in pharmacokinetic studies. J. Pharm. Biomed. Anal. 2017, 145, 364-371. [CrossRef] [PubMed]

Sample Availability: Samples are available from the authors.

(C) 2020 by the authors. Licensee MDPI, Basel, Switzerland. This article is an open access article distributed under the terms and conditions of the Creative Commons Attribution (CC BY) license (http://creativecommons.org/licenses/by/4.0/). 